\title{
KEBEBASAN BERKONTRAK DALAM JUAL BELI MENURUT KITAB UNDANG-UNDANG HUKUM PERDATA DAN KOMPILASI HUKUM EKONOMI SHARIAH
}

\author{
Sukardi \\ Fakultas Syari'ah dan Ekonomi Islam IAIN Pontianak \\ Email:dpd_nwkalbar@yahoo.co.id
}

\begin{abstract}
This article discusses the right to draw up a sale contract according to Indonesian civil code and the law compilation of Islamic economy. This right includes a statement that everyone is free to draw up a contract as long as it is not against laws, norms, and social order. The right to draw up a contract is stated in Indonesian civil code, article 1493 in connection with article 1338 clause (1). However, the contract must be based on conditions mentioned in article 1320. Meanwhile, according to the law of Islamic economy, the right to draw up a contract (Huriyyatul Aqad) must be in accordance with social system, ethics, and sharia - in other words, a contract drawn up against sharia is unacceptable.
\end{abstract}

Keywords: Freedom of contract, buy and sell, Kitab Undang-Undang Hukum Perdata, Hukum Ekonomi Shariah.

\begin{abstract}
Abstrak
Kebebasan berkontrak adalah suatu asas yang menyatakan bahwa setiap orang pada dasarnya boleh membuat kontrak (perjanjian) yang berisi dan macam apapun asal tidak bertentangan dengan undang-undang, kesusilaan dan ketertiban umum.Asas kebebasan berkontrak itu dituangkan oleh pembentuk undang-undang dalam pasal 1493 jo pasal 1338 ayat (1) Kitab Undang-Undang Hukum Perdata.Namun kebebasan berkontrak bukan berarti boleh membuat kontrak (perjanjian) secara bebas, tetapi kontrak (perjanjian) harus tetap dibuat dengan mengindahkan syaratsyarat untuk sahnya perjanjian, baik syarat umum sebagaimana disebut pasal 1320 Kitab Undang-Undang Hukum Perdata maupun syarat khusus untuk perjanjianperjanjian tertentu. Dalam Hukum Ekonomi Shariah, kebebasan berkontrak (Huriyyatul Aqad) yang dimaksud harus diartikan sebagai kebebasan yang terbatas, yaitu dibatasi tidak boleh menyimpang atau berlawanan dengan sistem umum, etika dan tujuan dasar syariat Islam. Artinya perjanjian jual beli dibolehkan selama isi dan bentuknya tidak dilarang oleh hukum Islam. Dengan demikian, perjanjian jual beli yang dibuat di luar ketentuan Hukum Ekonomi Shariah atau menyimpangi ketentuan hukum Islam, maka jual belinya menjadi batal.
\end{abstract}

Kata kunci : Kebebasan berkontrak; jual beli, Kitab Undang-Undang Hukum Perdata, Hukum Ekonomi Shariah. 


\section{Pendahuluan}

Kontrak atau dalam istilah sehari-hari sering disebut dengan perjanjian secara disadari maupun tidak disadari dipakai dalam komunitas masyarakat baik lisan maupun tertulis. Setiap perbuatan/kejadian yang melibatkan dua orang atau lebih dimana perbuatan yang disepakati menimbulkan akibat hukum berupa hak dan kewajiban pada masing-masing pihak merupakan aktualisasi lazim yang dilakukan.Salah satu contoh sederhana perjanjian yang dilakukan dalam masyarakat yaitu perjanjian jual beli dengan unsur utama adanya harga dan barang. Perjanjian jual beli antara pihak penjual dan pembeli berlaku mengikat sejak tercapainya kata sepakat (konsensus) antar kedua belah pihak.

Akad atau kontrak berasal dari bahasa Arabyang berarti ikatan atau simpulan baik ikatan yang nampak (hissyy) maupun tidak nampak (ma'nawy). ${ }^{1}$

Menurut Pasal 1313 KUHPerdata dikemukakan definisi perjanjian yaitu "suatu perbuatan dengan mana satu orang atau lebih mengikatkan dirinya terhadap satu orang atau lebih.”

Berdasarkan ketentuan yuridis tersebut, berarti perjanjian atau kontrak merupakan peristiwa hukum berupa kesepakatan untuk menciptakan hubungan hukum antar pihak-pihak yang terlibat dalam perjanjian.

Segala bentuk transaksi pada dasarnya boleh selama tidak bertentangan dengan prinsip-prinsip muamalat Islam. Ahmad Azhar Basyir dalam bukunya Asas-Asas Muamalat merumuskan tentang prinsip hukum Muamalat, antara lain:pada dasarnya segala bentuk muamalat adalah mubah, kecuali yang ditentukan lain oleh Al-Quran dan Al-Hadis, muamalat dilakukan atas dasar sukarela, tanpa mengandung unsur-unsur paksaan,muamalat dilakukan atas dasar pertimbangan mendatangkan manfaat dan menghindari mudharat dalam hidup manusia,muamalat dilaksanakan dengan memelihara nilai keadilan, menghindari unsur-unsur pengembalian kesempatan dan kesempitan. ${ }^{2}$

\footnotetext{
2008).

${ }^{1}$ Rahmani Timorita Yulianti, Asas-asas Perjanjian (Akad) Dalam Kontrak Syariah, (Yogyakarta,

${ }^{2}$ Ahmad Azhar Basyir, 2000, Asas-asas Hukum Muamalat,(Yogyakarta: UII Press, 2000). 15-16.
} 
Dalam Hukum Ekonomi Shariah, kebebasan berakad/kontrak atau biasa disebut juga dengan Huriyyatul Aqad, merupakan prinsip hukum Islam yang menyatakan bahwa setiap orang dapat membuat akad jenis apapun tanpa terikat pada nama-nama yang telah ditentukan dalam undang-undang shariah dan memasukan klausul apa saja ke dalam akad yang dibuatnya itu sesuai dengan kepentingannya sejauh tidak bertentangan dengan sistem umum, etika dan tujuan dasar syariat Islam.

Nash-nash Al-Quran dan Sunnah Nabi SAW sebagai otoritas utama sumber Hukum Islam serta kaidah-kaidah Hukum Islam menunjukan bahwa Hukum Islam menganut asas kebebasan berakad. Asas kebebasan berkontrak ini merupakan konkretisasi lebih jauh dari spesifikasi yang lebih tegas lagi terhadap asas ibadah dalam bermuamalah. Dalam Hukum Ekonomi Shariah berlandaskan Al Qur'an dan Sunnah Rasul. QS. Al-Maidah: 1memerintahkan kaum beriman untuk memenuhi janji-janji yang telah diikrarkan, baik janji prasetia hamba kepada Allah, maupun janji yang dibuat diantara sesama manusia, seperti yang bertalian dengan perkawinan, perdagangan dan sebagainya, selama janji itu tidak melanggar syariat Allah $^{3}$. Di samping itu, dalam kaidah Hukum Islam dikatakan bahwa, "pada asasnya akad itu adalah kesepakatan para pihak dan akibat hukumnya adalah adanya apa yang mereka tetapkan atas diri mereka melalui janji" ". Kaidah ini menunjukan adanya kebebasan berakad karena perjanjian itu dinyatakan berdasarkan kata kesepakatan para pihak dan akibat hukumnya adalah apa yang mereka tetapkan melalui janji.

Hukum perjanjian Islammengenal asas kebebasan berkontrak, yaitu kebebasan untukmembuat akad baru yang belum pernah dirumuskan oleh parafuqaha atau berisikan sejumlah klausula-klausula baru yangmencerminkan kepentingan masing-

\footnotetext{
${ }^{3}$ Yayasan Penyelenggara Penterjemah Pentafsir Al-Qur'an, Al-Qur'an dan Terjemahnya,(Jakarta: Depag RI,2006), 341.

${ }^{4}$ SyamsulAnwar, Hukum Perjanjian Syariah Teori dalam Fiqih Muamalat (Jakarta:Raja Grafindo Persada, 2007). 23.
} 
masing pihak. Dengan catatandilakukan secara suka rela serta tidak termasuk larangan syara'.

Pada dasarnya dapat dikatakan bahwa hukum Islam mengakui adanya kebebasan berkontrak. Kebebasan berkontrak yang dimaksud adalah kebebasan dalam menentukan bentuk-bentuk perjanjian yang digali berdasarkan dalil-dalil umum dalam Islam. Nash-nash Al-Qur'an dan Sunnah Nabi serta kaidah-kaidah fiqih menunjukkan bahwa hukum Islam menganut asas kebebasan berkontrak. Dalam AlQur'an (QS. Al Maidah : 1) Tuhan berfirman, "Wahai orang-orang yang berimanpenuhilah akad-akad'.Cara menyimpulkan kebebasan berkontrak dari ayat ini adalah bahwa perintah dalam ayat ini adalah wajib. Artinya memenuhi akad hukumnya wajib. Dapat disimpulkan bahwa bentuk akad apa saja wajib untuk dipenuhi. Dalam hadits Nabi dinyatakan: “Orang-orang muslim itu terikatkepada syarat-syarat (janji-janji) mereka. Hadits ini seperti ayat di atasmenunjukkan bahwa orang Islam terikatkepada apa saja syarat yang mereka perjanjikan.

Dengan demikian, menurut Hukum Ekonomi Shariah perjanjian sebenarnya tidak ada batasan yang ketat tentang bagaimana perjanjian tersebut dibentuk. Oleh karenanya, pengembangan macam dan bentuk perjanjian selanjutnya tidak ada larangan. Keberadaan perjanjian dapat ditelaah dengan melihat beberapa prinsip muamalah dalam Islam, di antaranya: pertama, pada dasarnya segala bentuk mualamah adalah mubah, kecuali yang dilarang dalam Al-Qur'an dan Sunnah; kedua, muamalah dilakukan atas dasar suka rela, tanpa mengandung unsur paksaan; ketiga, muamalah dilakukan atas dasar pertimbangan mendatangkan manfaat dan menghindari madharat dalam kehidupan masyarakat; keempat, muamalah dilaksanakan untuk memelihara keadilan, menghilangkan kezaliman (ketidakadilan), gharar (penuh tipu daya). ${ }^{5}$

Dalam Hukum Islam (Hukum Ekonomi Shariah), kebebasan berkontrak (Huriyyatul Aqad) yang dimaksud harus diartikan sebagai kebebasan yang terbatas, yaitu dibatasi tidak boleh menyimpang atau berlawanan dengan sistem umum, etika

\footnotetext{
${ }^{5}$ Basyir,...10.
} 
dan tujuan dasar syariat Islam. Dengan demikian, bahwa dalam KUHPerdata orang bukan hanya dibolehkan membuat perjanjian jual beli di luar yang ditentukan undang-undang, melainkan dibolehkan pula menyimpang dari undang-undang asalkan tidak bertentangan dengan kesusilaan dan ketertiban umum. Sedangkan dalam Hukum Ekonomi Shariah, kebebasan yang dimaksud harus diartikan sebagai kebebasan yang terbatas, yaitu dibatasi tidak boleh menyimpang atau berlawanan dengan Hukum Ekonomi Shariah. Artinya perjanjian jual beli dibolehkan selama isi dan bentuknya tidak dilarang oleh hukum Islam (baca : Hukum Ekonomi Shariah).

Sebagai perbandingan penerapan asas kebebasan berkontrak dalam bidang muamalat yaitu perjanjian mudharabah (pembiayaan) sekilas seolah-olah bertentangan dengan asas kebebasan berkontrak karenadraf akadnya ditentukan secara sepihak oleh pihak Bank dan pihak nasabahhanya tinggal tanda tangan saja.Akan tetapi kalau dicermati lebih mendalam atas proses yang terjadisebelum penandatanganan akad pembiayaan mudharabah antara pihak Bankdan Nasabah, dimana telah terjadi tawar menawar mengenai jumlahprosentase bagi hasil dari pendapatan keuntungan usaha yang akan diberikankepada pihak Bank, maka hal ini merupakan perwujudan dari asas kebebasanberkontrak. Perjanjian Mudharabah antara Bank Shariah (Kreditur) menyediakan modal sedangkan Nasabah (Debitur) menjadi pengelola dana, keuntungan dan kerugian dibagi menurut kesepakatan yang dituangkan dalam akad perjanjian mudharabah.

Berdasarkan uraian di atas, penulis tertarik untuk mengangkat dan menganalisa asas kebebasan berkontrak dalam perjanjian jual beli sebagai perjanjian yangkerap terjadi dalam kehidupan sehari-hari, dengan judul:"Kebebasan Berkontrak Dalam Jual Beli Menurut Kitab Undang-Undang Hukum Perdata Dan Kompilasi Hukum Ekonomi Shariah.”

\section{Kebebasan Berkontrak Dalam Jual Beli Menurut Kitab Undang-Undang Hukum Perdata}

Peraturan perundang-undangan mengenai hukum perjanjian bersifat menambah, yang artinya pihak-pihak dalam membuat persetujuan bebas untuk menyimpang daripada ketentuan-ketentuan tersebut dalam Kitab Undang-Undang Hukum Perdata. Mengenai kebebasan pihak-pihak untuk membuat persetujuan-persetujuan diadakan 
beberapa pembatasan, yaitu tidak boleh melanggar: hukum yang bersifat memaksa, ketertiban umum dan kesusilaan. ${ }^{6}$

Asas kebebasan berkontrak adalah suatu asas yang menyatakan bahwa setiap orang pada dasarnya boleh membuat kontrak (perjanjian) yang berisi dan macam apapun asal tidak bertentangan dengan undang-undang, kesusilaan dan ketertiban umum. ${ }^{7}$ Asas kebebasan berkontrak itu dituangkan oleh pembentuk undang-undang dalam pasal 1338 ayat (1) Kitab Undang-Undang Hukum Perdata.Namun kebebasan berkontrak bukan berarti boleh membuat kontrak (perjanjian) secarabebas, tetapi kontrak (perjanjian) harus tetap dibuat dengan mengindahkan syarat-syarat untuk sahnya perjanjian, baik syarat umum sebagaimana disebut pasal 1320 Kitab UndangUndang Hukum Perdata maupun syarat khusus untuk perjanjian-perjanjian tertentu.

Dalam Kitab Undang-Undang Hukum Perdata, asas kebebasan berkontrak yang dianut Buku III Kitab Undang-Undang Hukum Perdata ini merupakan sistem (materiil) terbuka sebagai lawan sistem (materiil) tertutup yang dianut Buku II Kitab Undang-Undang Hukum Perdata (Hukum Benda). Bahwa dengan kebebasan membuat perjanjian tersebut berarti orang dapat menciptakan hak-hak perseorangan yang tidak diatur dalam Buku III Kitab Undang-Undang Hukum Perdata akan tetapi diatur sendiri dalam perjanjian, sebab perjanjian yang dibuat secara sah berlaku sebagai undangundang bagi mereka yang membuatnya (pasal 1338 ayat (1) Kitab Undang-Undang Hukum Perdata).

Dikatakan, bahwa Hukum Benda mempunyai suatu sistem tertutup, sedangkan Hukum Perjanjian menganut sistem terbuka. Artinya macam-macam hak atas benda adalah terbatas dan peraturan-peraturan yang mengenai hak-hak atas benda itu bersifat memaksa, sedangkan Hukum Perjanjian memberikan kebebasan yang seluas-luasnya kepada masyarakat untuk mengadakan perjanjian yang berisi apa saja, asalkan tidak melanggar ketertiban umum dan kesusilaan. ${ }^{8}$

\footnotetext{
${ }^{6}$ Setiawan,Pokok-pokok Hukum Perikatan,_(Bandung: Bina Cipta, 1979). 10-11.

${ }^{7}$ Subekti,...13.

${ }^{8}$ Riduan, Syahrani, Seluk Beluk dan Asas Hukum Perdata,(Bandung:Alumni, 1992). 212.
} 
Pasal-pasal dari Hukum Perjanjian merupakan apa yang dinamakan hukum pelengkap (bahasa Inggris "optional law"), yang berarti bahwa pasal-pasal itu boleh disingkirkan manakala dikehendaki oleh pihak-pihak yang membuat suatu perjanjian. Mereka diperbolehkan membuat ketentuan-ketentuan sendiri yang menyimpang dari pasal-pasal Hukum Perjanjian. Mereka diperbolehkan mengatur sendiri kepentingan mereka dalam perianjian-perjanjian yang mereka adakan itu. Kalau mereka tidak mengatur sendiri sesuatu hal, itu berarti mereka mengenai hal tersebut akan tunduk kepada undang-undang.

Memang tepat sekali nama hukum pelengkap itu, karena benar-benar pasal-pasal dari Hukum Perjanjian itu dapat dikatakan melengkapi perjanjian-perjanjian yang dibuat secara tidak lengkap. Biasanya orang yang mengadakan suatu perjanjian tidak mengatur secara terperinci semua persoalan yang bersangkutan dengan perjanjian itu. Biasanya mereka hanya menyetujui hal-hal yang pokok saja, dengan tidak memikirkan soal-soal lainnya. Kalau para pihak mengadakan perjanjian jual beli misalnya, cukuplah apabila mereka sudah setuju tentang barang dan harganya. Tentang dimana barang harus diserahkan, siapa yang harus memikul biaya pengantaran barang, tentang bagaimana kalau barang itu musnah dalam perjalanan, soal-soal itu lazimnya tidak dipikirkan dan tidak diperjanjikan. Cukuplah mengenai soal itu para pihak tunduk saja pada hukum dan undang-undang. Biasanya juga tidak ada perselisihan mengenai soalsoal itu, tetapi bilamana timbul perselisihan, maka sebaiknya para pihak menyerahkan saja kepada hukum dan undang-undang. ${ }^{9}$

Sistem terbuka yang mengandung suatu asas kebebasan membuat perjanjian, dalam Kitab Undang-Undang Hukum Perdata lazimnya disimpulkan dalam pasal 1493 dan pasal 1338 ayat (1). Dalam pasal 1493 Kitab Undang-Undang Hukum Perdata ditegaskan; Kedua belah pihak diperbolehkan dengan persetujuan-persetujuan istimewa memperluas atau mengurangi kewajiban yang ditetapkan oleh undangundang ini; bahkan mereka diperbolehkan mengadakan persetujuan bahwa si penjual tidak akan diwajibkan menanggung sesuatu apapun. Kata memperluas atau

\footnotetext{
${ }^{9}$ Subekti,...128.
} 
mengurangi, mengisyaratkan bahwa dalam Kitab Undang-Undang Hukum Perdata produsen dan konsumen boleh membuat perjanjian yang isinya mengurangi salah satu kewajiban sebagai produsen atau konsumen. Sebaliknya mereka pun diperkenankan membuat perjanjian yang isinya menambah kewajiban masing-masing. Kebebasan di sini diberikan karena mereka setuju atau sepakat terhadap hal itu. Tampaknya asas kesepakatan dan asas kebebasan berkontrakmenempati urutan pertama dan bagian terpenting dalam hukum perjanjian, khususnya perjanjian jual beli perspektif hukum perdata. Adapun kata si penjual tidak akan diwajibkan menanggung, ini menunjukkan bahwa dalam hukum perdata, produsen diperkenankan tidak menanggung risiko terhadap kerusakan barang atau risiko cacatnya barang. Perkenan ini hanya dimungkinkan manakala mendapat persetujuan konsumen.

Ketentuan pasal 1493 Kitab Undang-Undang Hukum Perdata tidak berdiri sendiri melainkan didukung oleh Pasal 1338 ayat (1), yang berbunyi demikian:"Semua perjanjian yang dibuat secara sah berlaku sebagai undang-undang bagi mereka yang membuatnya". Dengan menekankan pada perkataan semua, maka pasal tersebut seolah-olah berisikan suatu pernyataan kepada masyarakat bahwa orang diperbolehkan membuat perjanjian yang berupa dan berisi apa saja (atau tentang apa saja) dan perjanjian itu akan mengikat mereka yang membuatnya seperti suatu undang-undang. Misalnya barang yang diperjual belikan, menurut hukum perjanjian harus diserahkan di tempat di mana barang itu berada sewaktu perjanjian jual beli ditutup. Tetapi. para pihak leluasa untuk memperjanjikan bahwa barang harus diserahkan di kapal, di gudang, diantar ke rumah si pembeli dan lain-lain, dengan pengertian bahwa biayabiaya pengantaran harus dipikul oleh si penjual.

Selanjutnya, sistem terbuka dari Hukum Perjanjian itu juga mengandung suatu pengertian, bahwa perjanjian-perjanjian khusus yang diatur dalam undang-undang hanyalah merupakan perjanjian yang paling terkenal saja dalam masyarakat pada waktu Kitab Undang-undang Hukum Perdata dibentuk. Misalnya, Undang-undang hanya mengatur perjanjian-perjanjian jual beli dan sewa-menyewa, tetapi dalam praktek timbul suatu macam perjanjian yang dinamakan sewa beli, yang merupakan suatu campuran antara jual beli dan sewa-menyewa. Oleh karena pihak pembeli tidak 
mampu membayar harga barang sekaligus, diadakanlah perjanjiandimana si pembeli diperbolehkan mencicil harga itu dalam beberapa angsuran, sedangkan hak milik (meskipun barangnya sudah dalam kekuasaan si pembeli) baru berpindah kepada si pembeli apabila angsuran yang penghabisan telah terbayar lunas. Selama harga itu belum dibayar lunas, barangnya disewa oleh pembeli. Dengan demikian terciptalah suatu perjanjian yang dinamakan sewa beli itu.

Dari uraian di atas jelaslah bahwa asas kebebasan berkontrak adalah suatu asas yang menyatakan bahwa setiap orang pada dasarnya boleh membuat kontrak (perjanjian) yang berisi dan macam apapun asal tidak bertentangan dengan undangundang, kesusilaan dan ketertiban umum. Asas kebebasan berkontrak itu dituangkan oleh pembentuk undang-undang dalam pasal 1493 jo.1338 ayat (1) Kitab UndangUndang Hukum Perdata. Sistem ini mengandung konsekuensi dibebaskannya orang membuat perjanjian jual beli menurut kehendak kedua belah pihak meskipun isi perjanjian itu tidak diatur undang-undang atau bahkan menyimpang dari undangundang.

\section{Kebebasan Berkontrak Dalam Jual Beli Menurut Hukum Ekonomi Shariah}

Dalam Hukum Ekonomi Shariah juga menganut asas kebebasan berkontrak yang disebut juga dengan Hurriyatul Aqad yang merupakan prinsip hukum Islam yang menyatakan bahwa setiap orang dapat membuat akad jenis apapun tanpa terikat pada nama-nama yang telah ditentukan dalam undang-undang syariat dan memasukkan klausul apa saja ke dalam akad yang dibuatnya itu sesuai dengan kepentingannya sejauh tidak bertentangan dengan sistem umum, etika dan tujuan dasar syariat Islam.

Suatu perjanjian (Aqad) harus dilandasi adanya kebebasan berkehendak dan kesukarelaan dari masing-masing pihak yang mengadakan transaksi sebagaimana firman Allah SWT (Q.S An-Nisa : 29), artinya :

"Wahai orang-orang yang beriman! janganlah kamu saling memakan harta sesamamu dengan jalan yang batil (tidak benar), kecuali dengan dalam perdagangan yang berlaku dengan suka sama-suka di antara kamu." 
Hukum tentang kontrak prinsipnya tergolong kedalam hukum mengatur, artinya bahwa hukum tersebut baru berlaku sepanjang para pihak tidak mengatur lain. Jika para pihak dalam berkontrak mengaturnya secara lain dari yang diatur dalam hukum kontrak, maka yang berlaku adalah apa yang diatur sendiri oleh para pihak tersebut kecuali Undang-Undang menentukan lain. Salah satu asas dalam Hukum Kontrak Islam (baca : Hukum Ekonomi Shariah) adalah kebebasan berkontrak, artinya para pihak bebas membuat kontrak dan mengatur sendiri kontrak tersebut sepanjang memenuhi ketentuan sebagai berikut ${ }^{10}$ :

1) Tidak dilarang oleh peraturan shariah (Undang-Undang). Maksudnya bahwa kontrak yang diadakan oleh para pihak itu bukanlah perbuatan yang bertentangan dengan hukum / perbuatan yang melawan hukum Shariah. Sebab kontrak yang bertentangan dengan ketentuan hukum syara' adalah tidak sah, dan dengan sendirinya tidak ada kewajiban bagi masing-masing pihak untuk menepati atau melaksanakan ketentuan tersebut atau dengan perkataan lain apabila isi kontrak itu merupakan perbuatan yang melawan hukum, maka kontrak yang diadakan dengan sendirinya batal demi hukum.

2) Sesuai dengan ketentuan yang berlaku.

3) Sepanjang kontrak tersebut dilaksanakan dengan itikad baik.

Kontrak diadakan oleh para pihak dengan itikad baik haruslah didasarkan kepada kesepakatan kedua belah pihak, dimana masing-masing pihak ridho / rela akan isi kontrak tersebut dan merupakan kehendak bebas masing-masing pihak sehingga mereka mempunyai itikad baik untuk menepati kontrak tersebut.

Dalam Hukum Ekonomi Shariah, transaksi jual beli telah terjadi dan mengikat kedua belah pihak pada saat mengucapkan 'aqd (baca: 'aqad) untuk mengadakan suatu perjanjian. Saat mengucapkan pernyataan untuk menjual suatu barang, begitu juga pihak lain, berarti ia telah menyatakan kesediaannya untuk membeli, terikatlah kedua belah pihak untuk melaksanakan perjanjian tersebut.

\footnotetext{
${ }^{10}$ Hamzah Ya'cub, Fiqh al- Muamalah,_(Bandung: CV. Diponegoro, 1992). 75.
} 
Transaksi jual beli dianggap terjadi dan mengikat pada saat menyatakan keinginan untuk menjual dan menyatakan keinginan untuk membeli antara kedua belah pihak. Pernyataan tersebut mengandung komitmen untuk mengadakan suatu perjanjian sehingga berakibat mewajibkan penjual untuk menyerahkan barang dan berhak menerima harga penjualan, demikian juga pembeli berkewajiban membayar harga serta berhak menerima barang pembelian tersebut.

Dalam Hukum Ekonomi Shariah, yang menjadi dasar untuk adanya perjanjian adalah pernyataan-pernyataan yang diucapkan serta mengandung janji-janji antara kedua belah pihak untuk melaksanakan suatu perbuatan hukum tertentu. Setelah terwujudnya suatu janji, timbullah hubungan hukum yang mengikat. Masing-masing pihak berkewajiban untuk melaksanakannya sebagaimana pernyataan yang telah diucapkan bersama. Hal ini dikarenakan dalam hukum Islam mewajibkan kepada umatnya untuk menunaikan setiap janji yang telah mereka buat secarasuka rela. Janji itu diumpamakan sebagai tali yang justru dapat putus dan dapat menjadi kuat.

Selanjutnya, hukum Islam menetapkan bahwa setiap janji itu harus dipenuhi. Hal ini sesuai dengan firman Allah SWT QS. Al-Maidah : 1, artinya "Wahai orangorang beriman! Penuhilahjanji-janjimu.'Perintah ini merupakan suatu kewajiban yang harus dilaksanakan. Apabila diucapkan suatu janji untuk mengadakan transaksi jual beli, terikatlah kedua belah pihak antara calon pembeli dan calon penjual. Janji itu harus dengan kata-kata jual dan beli, misalnya, penjual berkata, "Sudah saya jual kepadamu", dan pembeli menjawab, "Sudah saya beli darimu" .

Perjanjian jual beli yang dibuat di luar ketentuan hukum Islam atau menyimpangi ketentuan hukum Islam, maka jual belinya menjadi batal atau tidak sah. Jadi apabila misalnya penjual meminta dikurangi kewajibannya seperti lepas tangan terhadap cacat barang atau kerusakan barang maka perjanjian jual beli dengan syarat seperti itu menjadi batal meskipun pembeli sepakat. Implikasinya maka bagi produsen dan konsumen dapat menarik kembali perjanjian atau membatalkan perjanjian jual beli, manakala menyimpang dari ketentuan hukum Islam, apalagi jika hukum Islam melarangnya. Pembatalan ini bisa terjadi bila salah satu pihak membatalkan tanpa perlu adanya kesepakatan. Jadi meskipun tidak bertentangan dengan ketertiban umum dan kesusilaan, perjanjian jual beli dengan syarat tersebut dianggap batal. 
Kebebasan berkontrak tersebut memiliki limitasi terhadap hal-hal yang sudah jelas dilarang dalam syariat. Tujuan dari limitasi tersebut adalah untuk menjaga agar tidak terjadi penganiayaan antara sesama manusia melalui kontrak yang dibuatnya. Limitasi tersebut antara lain larangan bertransaksi secara ribawi, larangan perjudian atau untung-untungandan larangan gharar(ketidakpastian risiko, spekulasi atau bahaya yang dapat menyesatkan pihak lain) termasuk larangan ijon (mukhabarah) atau menjual barang yang tidak dapat diserahkan karena belum dikuasai dalam melakukan transaksi. $^{11}$

Sementara di dalam Hukum Islam terdapat juga asas-asas hukum kontrak,antara lain:

a. Kebebasan (Al-Hurriyyah)

Pihak-pihak yang melakukan kontrak mempunyai kebebasan untuk melakukan suatu perjanjian, baik tentang obyek maupun syarat-syarat perjanjiannya,termasuk menetapkan cara-cara penyelesaian sengketa apabila terjadi sengketa kemudian hari.

b. Persamaan dan kesetaraan (Al-Musawah)

Asas ini memberikan landasan bahwa kedua belah pihak yang melakukan kontrak mempunyai kedudukan yang sama atau setara antara yang satu dengan yang lain.

c. Keadilan (Al-Adalah)

Pelaksanaan asas ini dalam kontrak dituntut untuk bertindak benar dalam mengungkapkan kehendak dan keadaan,memenuhi perjanjian yang telah disepakati bersama dan memenuhi segala hak dan kewajiban,tidak saling menzalimi dan dilakukannya secara berimbang tanpa merugikan pihak yang lain yang terlibat dalam kontrak.

d. Kerelaan (Al-Ridha)

Asas ini menyatakan bahwa semua kontrak yang dilakukan para pihak harusdidasarkan pada kerelaan semua pihak yang membuatnya. Kerelaan para

\footnotetext{
${ }^{11}$ Gemala Dewi, Aspek-aspek Hukum dalam Perbankan dan Asuransi Syariah di Indonesia(Jakarta:Prenada Media, 2004). 193-194.
} 
pihak yang berkontrak adalah jiwa setiap kontrak yang islami dan dianggap sebagai syarat terwujudnya semua transaksi.

e. Ash-Shidq (Kejujuran dan Kebenaran)

Kejujuran adalah nilai etika yang paling tinggi dalam Islam. Islam mengajarkan ummatnya untuk jujur dalam segala hal dan melarang dengan tegas kebohongan dan penipuan dalam bentuk apapun. Nilai kebenaran ini memberikan pengaruh pada pihak-pihak yang membuat perjanjian untuk tidak berdusta ,menipu, dan melakukan penipuan. Pada saat asas ini tidak terpenuhi ,legalitas akad asas yang dibuat menjadi rusak.

f. Tertulis (Al-Kitabah)

Asas lain dalam melakukan kontrak adalah harus dibuat secara tertulis supaya tidak terjadi di kemudian hari. ${ }^{12}$

\section{Persamaan dan Perbedaan antara Kitab Undang-Undang Hukum Perdata dan Hukum Ekonomi Shariah Terhadap Asas Kebebasan Berkontrak dalam Jual Beli}

Secara umum terlihat banyak kesamaan tentang hukum perjanjian antara kedua sistem hukum tersebut (seperti pada uraian diatas).Keduanya mengatur tentang unsurunsurperjanjian, syarat-syarat perjanjian, kebebasan membuat perjanjian dan berakhirnya suatu perjanjian.

Sebagaimana telah dikemukakan sebelumya bahwa asas kebebasan berkontrak dalam Hukum Ekonomi Shariah dan Kitab Undang-Undang Hukum Perdata, pada kedua hukum itu memiliki persamaan dan perbedaan. Persamaannya, bahwa Hukum Ekonomi Shariah dan Kitab Undang-Undang Hukum Perdata sama-sama menganut asas kebebasan berkontrak. Sebagai contoh bahwa suatu kontrak dalam Hukum Ekonomi Shariah harus dilandasi adanya kebebasan berkehendak dan kesukarelaan dari masing-masing pihak yang mengadakan transaksi asalkan tidak bertentangan dengan sistem umum, etika dan tujuan dasar syariat Islam.

\footnotetext{
${ }^{12}$ Imanuel Raja Damaitu,Perbandingan Asas Perjanjian Dalam Kontrak Dalam Hukum Islam dan Kitab Undang-Undang Hukum Perdata, (Yogyakarta, 2008).
} 
Syariat Islam memberikan kebebasan kepada setiap orang untuk melakukan akad sesuai yang diinginkannya, sebaliknya apabila ada unsur pemaksaan atau pemasungan kebebasan akan menyebabkan legalitas kontrak yang dihasilkan batal atau tidak sah. Asas ini menggambarkan prinsip dasar bidang muamalah yaitu kebolehan (mubah) yang mengandung arti memberi kesempatan luas perkembangan bentuk dan macam muamalah baru sesuai dengan perkembangan kebutuhan hidup masyarakat. Namun, kebebasan berkontrak tersebut memiliki limitasi terhadap hal-hal yang sudah jelas dilarang dalam Syariat. Tujuan dari limitasi tersebut adalah untuk menjaga agar tidak terjadi penganiayaan antara sesama manusia melalui kontrak yang dibuatnya. Limitasi tersebut antara lain larangan bertransaksi secara ribawi, larangan perjudian atau untung-untungan, dan larangan gharar (ketidakpastian risiko, spekulasi atau bahaya yang dapat menyesatkan pihak lain, yang di sini juga termasuk larangan ijon (mukhabarah) atau menjual barang yang tidak dapat diserahkan karena belum dikuasai dalam melakukan transaksi.

Di samping itu, terdapat pula larangan-larangan yang menyangkut sistem dalam bertransaksi, seperti larangan monopoli, larangan menimbun barang untuk menaikkan harga, larangan menaikkan penawaran untuk mengelabui pembeli lain bukan untuk sungguh-sungguh membeli, larangan perampasan atau akad yang mengandung penipuan dan merampas milik orang lain tanpa izin. Demikian pula dilarang melakukan eksploitasi dan unfair dealings serta masih banyak lagi ketentuan dalam perdagangan yang diatur secara jelas-jelas dilarang pelaksanaannya.

Dalam Kitab Undang-Undang Hukum Perdata, asas kebebasan berkontrak adalah suatu asas yang menyatakan bahwa setiap orang pada dasarnya boleh membuat kontrak (perjanjian) yang berisi dan macam apapun asal tidak dilarang undangundang, kesusilaan dan ketertiban umum. Pengertian ini menunjukkan bahwa Kitab Undang-Undang Hukum Perdata memberi kebebasan pada para pihak untuk membuat perjanjian dalam bentuk apa pun. Hal ini dapat dimengerti karena hukum perjanjian menganut sistem terbuka, para pihak diberi peluang untuk membuat perjanjian apa saja sesuai dengan kesepakatan bersama. Asas kebebasan berkontrak itu dituangkan 
oleh pembentuk undang-undang dalam pasal 1338 ayat (1) Kitab Undang-Undang Hukum Perdata.

Dengan kebebasan membuat perjanjian tersebut berarti orang dapat menciptakan hak-hak perseorangan yang tidak diatur dalam Buku III Kitab Undang-Undang Hukum Perdata akan tetapi diatur sendiri dalam perjanjian, sebab perjanjian yang dibuat secara sah berlaku sebagai undang-undang bagi mereka yang membuatnya (pasal 1338 ayat (1) Kitab Undang-Undang Hukum Perdata). Namun kebebasan berkontrak bukan berarti boleh membuat kontrak (perjanjian) secarabebas, tetapi kontrak (perjanjian) harus tetap dibuat dengan mengindahkan syarat-syarat untuk sahnya perjanjian, baik syarat umum sebagaimana disebut pasal 1320 Kitab Undang-Undang Hukum Perdata maupun syarat khusus untuk perjanjian-perjanjian tertentu.

Dengan adanya kebebasan berkontrak maka kedudukan rangkaian pasal-pasal Buku III KUHPerdata khususnya pasal-pasal pada titel V s/d XVIII banyak yang hanya bersifat sebagai hukum pelengkap (aanvallend recht) saja. Artinya pasal-pasal tersebut boleh dikesampingkan sekiranya para pihak pembuat perjanjian menghendakinya, dan para pihak pembuat perjanjian diperbolehkan menciptakan ketentuan sendiri untuk mengatur kepentingan mereka sesuai dengan apa yang mereka kehendaki. Pasal-pasal tersebut baru mengikat terhadap mereka, jika mereka tidak mengatur sendiri kepentingannya atau mengaturnya dalam perjanjian tetapi tidak lengkap, maka hal-hal yang tidak diatur tersendiri itu diberlakukan pasal-pasal hukum perikatan.

Selanjutnya dengan adanya asas kebebasan berkontrak itu maka perjanjianperjanjian khusus yang disebut pada titel V s/d XVIII yang dikenal dengan sebutan perjanjian-perjanjian bernama itu hanyalah sebagai contoh belaka. Karenanya orang boleh membuat perjanjian yang lain daripada contoh tersebut atau membuatnya secara sama dengan salah satu daripadanya sesuai dengan kebutuhan untuk apa perjanjian termaksud dibuat.

Sedangkan sebagai perbedaannya, bahwa dalam Kitab Undang-Undang Hukum Perdata orang bukan hanya dibolehkan membuat perjanjian jual beli yang ditentukan undang-undang, melainkan juga dibolehkan pula menyimpang dari undang-undang asalkan tidak bertentangan dengan kesusilaan dan ketertiban umum. Sedang dalam 
Hukum Ekonomi Shariah, kebebasan yang dimaksud harus diartikan sebagai kebebasan yang terbatas, yaitu dibatasi tidak boleh menyimpang atau berlawanan dengan sistem umum, etika dan tujuan dasar syariat Islam.

Untuk jelasnya perbedaan Asas Kebebasan Berkontrak ditinjau dari Kitab Undang-Undang Hukum Perdata dan Hukum Ekonomi Shariah, dapat diuraikan sebagai berikut :

1) Dalam Hukum Ekonomi Shariah setiap orang dapat membuat akad jenis apapun tanpa terikat kepada nama-nama yang telah ditentukan dalam undang-undang shariah dan memasukan klausul apa saja kedalam akad yang dibuatnya, sesuai dengan kepentingannya selama tidak berakibat tidak memakan harta sesama dengan jalan batil. Hanya saja kebebasan membuat akad dalam Hukum Ekonomi Shariah (Islam) tidak mutlakmelainkan dibatasi. Artinya dalam melakukan suatu perjanjian, bentuk dan isi perjanjian ditentukan telah disepakati, maka perjanjian tersebut mengikat para pihak yang menyepakatinya dan harus dilaksanakan sejalan hak dan kewajibannya. Namun kebebasan ini tidak absolut sepanjang tidak bertentangan dengan Shariah Islam maka perjanjian tersebut boleh dilaksanakan.

Sedangkan menurut Hukum Perdata (baca : Kitab Undang-Undang Hukum Perdata) setiap orang bebas mengadakan perjanjian apa saja, baik yang sudah diatur atau belum diatur dalam undang-undang. Tetapi kebebasan tersebut dibatasi tiga hal yaitu; tidak dilarang oleh undang-undang, tidak bertentangan dengan ketertiban umum dan tidak bertentangan dengan kesusilaan. Pembatasan terhadap asas kebebasan berkontrak juga dapat disimpulkan melalui Pasal 1338 ayat (3) yang menyatakan bahwa suatu perjanjian hanya dilaksanakan dengan itikad baik. Oleh karena itu para pihak tidak dapat menentukan sekehendak hatinya klausul-klausul yang terdapat dalam perjanjiian tetapi harus didasarkan dan dilaksanakan dengan itikad baik, perjanjian yang didasarkan pada itikad buruk misalnya penipuan. Akibat hukum atas perjanjian tersebut adalah dapat dibatalkan.

Dalam KUHPerdata, dimaksudkan kebebasan seseorang untuk membuat perjanjian macam apapun dan berisi apa saja sesuai dengan kepentingannya, dalam batasbatas kesusilaan dan ketertiban umum, sekalipun perjanjian tersebut bertentangan 
dengan aturan (pasal) hukum perjanjian. Misalnya menurut hukum perjanjian, barang yang diperjualbelikan oleh para pihak harus diserahkan ditempat dimana barang tersebut berada pada waktu perjanjian tersebut ditutup. Namun demikian para pihak dapat menentukan lain. Misalnya si penjual harus mengantarkan dan menyerahkan barang tersebut dirumah si pembeli.

Dengan asas kebebasan berkontrak ini, para pihak yang membuat dan mengadakan perjanjian diperbolehkan untuk menyusun dan membuat kesepakatan atau perjanjian yang melahirkan kewajiban apa saja, selama dan sepanjang prestasi yang wajib dilakukan tersebut bukanlah sesuatu yang terlarang. Hal ini sesuai ketentuan Pasal 1337 KUHPerdata yang menyatakan : "Suatu sebab adalah terlarang apabila dilarang oleh undang-undang, atau apabila berlawanan dengan kesusilaan baik atau ketertiban umum.

Dengan demikian, secara garis besar perbedaan yang sangat relevan dan signifikan tentang perjanjian menganut asas kebebasan berkontrak antara kedua sistem hukum tersebut adalah Perjanjian menurut Hukum Ekonomi Shariah sah bila tidak bertentangan dengan syariat sedangkan menurut hukum perdata (Kitab Undang-Undang Hukum Perdata) perjanjian sah bila tidak bertentangan ketertiban umum dan kesusilaan.

2) Perjanjian jual beli yang dibuat di luar ketentuan Hukum Ekonomi Shariah atau menyimpangi ketentuan hukum Islam, maka jual belinya menjadi batal. Jadi bila misalnya penjual meminta dikurangi kewajibannya seperti lepas tangan terhadap cacat barang atau kerusakan barang maka perjanjian jual beli dengan syarat seperti itu menjadi batal meskipun pembeli sepakat. Implikasinya maka bagi produsen dan konsumen dapat menarik kembali perjanjian atau membatalkan perjanjian jual beli, manakala menyimpang dari ketentuan Hukum Ekonomi Shariah apalagi jika hukum Islam melarangnya. Pembatalan ini bisa terjadi bila salah satu pihak membatalkan tanpa perlu adanya kesepakatan. Jadi meskipun tidak bertentangan dengan ketertiban umum dan kesusilaan perjanjian jual beli dengan syarat tersebut dianggap batal.

Hal ini berbeda dengan ketentuan dalam Kitab Undang-Undang Hukum Perdata, pasal 1493 yang berbunyi : "Kedua belah pihak diperbolehkan dengan persetujuan- 
persetujuan istimewa memperluas atau mengurangi kewajiban yang ditetapkan oleh undang-undang ini; bahkan mereka diperbolehkan mengadakan persetujuan bahwa si penjual tidak akan diwajibkan menanggung sesuatu apapun.”

Kata memperluas atau mengurangi, mengisyaratkan bahwa dalam KUHPerdata antara penjual dan pembeli boleh membuat perjanjian yang isinya mengurangi salah satu kewajiban sebagai penjual dan pembeli. Sebaliknya mereka pun diperkenankan membuat perjanjian yang isinya menambah kewajiban masingmasing. Kebebasan di sini diberikan karena mereka setuju atau sepakat terhadap hal itu. Tampaknya asas kesepakatan menempati urutan pertama dan bagian terpenting dalam hukum perjanjian, khususnya perjanjian jual beli berdasarkan perspektif hukum perdata.

Dengan demikian, Pasal 1493 KitabUndang-Undang Hukum Perdata mengisyaratkan orang diperbolehkan dapat mengadakan perjanjian mengenai apa pun juga, dengan kata lain dikenal dengan istilah "asas kebebasan berkontrak". Akan tetapi terhadap kebebasan ini juga ada pembatasannya yaitu asaltidak dilarang oleh Undang-Undang, tidak bertentangan dengan kesusilaan dan ketertiban umum. $^{13}$

\section{Simpulan}

Ada beberapa hal yang dapat ditarik sebagai kesimpulan dengan mencermati uraian sebelumnya, diantaranya :

1. Asas kebebasan berkontrak dalam jual beli menurut Kitab Undang-Undang Hukum Perdata adalah suatu asas yang menyatakan bahwa setiap orang pada dasarnya boleh membuat kontrak (perjanjian) jual beli yang berisi dan macam apa pun asal tidak bertentangan dengan kesusilaan dan ketertiban umum. Hal ini sebagaimana ditegaskan dalam pasal 1493 jo 1338 (1) Kitab Undang-Undang Hukum Perdata.

2. Dalam Hukum Ekonomi Shariah, asas kebebasan berkontrak (Huriyyatul Aqad) dalam jual beli, menyatakan bahwa setiap orang dapat membuat akad jenis apapun tanpa terikat pada nama-nama yang telah ditentukan dalam undang-undang syariat

\footnotetext{
${ }^{13}$ Sri Soedewi,Masjchoen Sofwan,.... 12.
} 
dan memasukan klausul apa saja ke dalam akad yang dibuatnya itu sesuai dengan kepentingannya sejauh tidak bertentangan dengan sistem umum, etika dan tujuan dasar syariat Islam. Persamaan antara Kitab Undang-undang Hukum Perdata dan Hukum Ekonomi Shariah adalah pada kedua sistem hukum itu menganut asas kebebasan berkontrak. Kebebasan tersebut diantaranya bebas untuk menentukan dengan siapa mengadakan perjanjian, bebas dalam menentukan bentuk dan isi perjanjian serta memilih hukum yang berlaku atas perjanjian yang diadakan.

3. Perbedaan antara Kitab Undang-undang Hukum Perdata dengan Hukum Ekonomi Shariah adalah dalam Kitab Undang-undang Hukum Perdata orang bukan hanya dibolehkan membuat perjanjian jual beli yang ditentukan undang-undang, tetapi juga boleh menyimpang dari ketentuan undang-undang asalkan tidak bertentangan dengan kesusilaan dan ketertiban umum. Sedangkan dalam Hukum Ekonomi Shariah, kebebasan berkontrak (Huriyyatul Aqad) yang dimaksud harus diartikan sebagai kebebasan yang terbatas, yaitu dibatasi tidak boleh menyimpang atau berlawanan dengan sistem umum, etika dan tujuan dasar syariat Islam. Artinya perjanjian jual beli dibolehkan selama isi dan bentuknya tidak dilarang oleh hukum Islam.Dengan demikian, perjanjian jual beli yang dibuat di luar ketentuan Hukum Ekonomi Shariah atau menyimpangi ketentuan hukum Islam, maka jual belinya menjadi batal. Contohnya Perjanjian jual dengan obyek yang tidak dibolehkan dalam hukum Islam (Jual Beli dengan sistem Ijon :pembayaran dilakukan terhadap obyek yang belum pasti). Implikasinya maka bagi produsen dan konsumen dapat menarik kembali perjanjian atau membatalkan perjanjian jual beli, manakala menyimpang dari ketentuan Hukum Ekonomi Shariah apalagi jika hukum Islam melarangnya. Pembatalan ini bisa terjadi bila salah satu pihak membatalkan tanpa perlu adanya kesepakatan. Jadi meskipun tidak bertentangan dengan ketertiban umum dan kesusilaan perjanjian jual beli dengan syarat tersebut dianggap batal. Hal ini berbeda apabila dibandingkan dengan ketentuan dalam Kitab UndangUndang Hukum Perdata, pasal 1493 yang berbunyi : "Kedua belah pihak diperbolehkan dengan persetujuan-persetujuan istimewa memperluas atau mengurangi kewajiban yang ditetapkan oleh undang-undang ini; bahkan mereka 
diperbolehkan mengadakan persetujuan bahwa si penjual tidak akan diwajibkan menanggung sesuatu apapun."

Artinya para pihak yang mengadakan perjanjian boleh melakukan kontrak (perjanjian) dalam hal memperluas atau mengurangi kewajiban yang ditetapkan undang-undang, bahkan dalam hal meniadakan kewajiban penjual untuk menanggung sesuatu risiko (cacat) atas barang yang dijperjualbelikan asalkan hal demikian merupakan kesepakatan kedua belah pihak.

\section{Daftar Pustaka}

Basyir, Azhar Ahmad, Asas-asas Hukum Muamalat, (Yoygakarta:UII Press, 2000).

Dewi, Gemala, Aspek-aspek Hukum dalam Perbankan dan Asuransi Shariah di Indonesia, (Jakarta: Prenada Media, 2004).

Ya'cub, Hamzah, Fiqh al- Muamalah, (Bandung:CV. Diponegoro, 1992).

Riduan, Syahrani, Seluk Beluk dan Asas Hukum Perdata, (Bandung:Alumni, 1992).

Setiawan, Pokok-pokok Hukum Perikatan,_Bandung: Bina Cipta, 1979).

Soedewi,Sri, Masjchoen,Sofwan, Hukum Perdata Hukum Benda, (Yogyakarta.Liberty, 1981).

Subekti, Aneka Perjanjian, (BandungAlumni,1981).

Anwar,Syamsul, Hukum Perjanjian Shariah Teori dalam Fiqih Muamalat, (JakartaRaja Grafindo Persada, 2007).

\section{Jurnal}

ImanuelRajaDamaitu,Perbandingan Asas Perjanjian Dalam Kontrak Dalam Hukum Islam dan Kitab Undang-Undang Hukum Perdata, Jurnal Ar-Riba, Volume II,Nomor 1, (Yogyakarta, Juli 2008).

Rahmani Timorita Yulianti,Asas-asas Perjanjian (Akad) Dalam Kontrak Shariah, Jurnal La-Riba, Volume II, Nomor 1 (Yogyakarta,Juli 2008). 